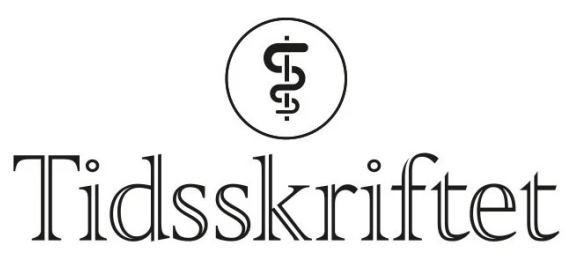

DEN NORSKE LEGEFORENING

\title{
Glemmer vi gravide kvinner og ufødte barn i covid-19-pandemien?
}

LEDER

\section{CATHRINE EBBING}

cathrine.ebbing@helse-bergen.no

Cathrine Ebbing er spesialist i fødselshjelp og kvinnesykdommer, overlege ved Kvinneklinikken ved Haukeland universitetssjukehus og førsteamanuensis ved Universitetet i Bergen.

Forfatteren har fylt ut ICMJE-skjemaet og oppgir ingen interessekonflikter.

\section{METTE BREKKE}

Mette Brekke er spesialist i allmennmedisin og professor ved Universitetet i Oslo. Forfatteren har fylt ut ICMJE-skjemaet og oppgir ingen interessekonflikter.

\section{Covid-19-pandemien utgjør en biopsykososial helserisiko for gravide, fødende og deres barn verden over.}

Covid-19 rammer gravide, fødende og deres barn hardere enn vi har trodd. I tillegg til risikoen for alvorlig maternell sykdom øker også faren for alvorlige svangerskapskomplikasjoner som for tidlig fødsel, preeklampsi og dødfødsel $(\underline{1}, \underline{2})$.

Eberhard-Gran og medarbeidere beskriver nå i Tidsskriftet at i deres utvalg av kvinner som fødte i Norge under pandemien, hadde en tredel høy skår for depressive symptomer (3). Det er tre ganger høyere enn i en studie fra ti år tilbake, og i tråd med funn fra andre deler av verden (4). Det er grunn til å tro at denne $ø$ kte forekomsten av depressive symptomer også gjelder under svangerskapet og ikke bare i barseltiden. Dette er foruroligende på bakgrunn av kunnskapen vi har om at stress i svangerskapet synes å påvirke barnets helse på en ugunstig måte (5). Eberhard-Gran og medarbeidere fant at kvinner med lavest utdanning anga mest problemer, noe som bekrefter at pandemien øker helseforskjellene i samfunnet. De fant også at kvinnene som fødte under pandemien, opplevde dårligere barselomsorg, og at mer enn halvparten av de som hadde psykiske helseplager, oppga at de ikke fikk god nok hjelp.

«Kanskje er det ikke covid-19 i seg selv som er pandemiens største trussel for gravide og kommende generasjoner» 
Studier tyder på at ved SARS-CoV-2-infeksjon er det morens immunrespons - snarere enn selve viruset - som kan være skadelig for fosteret (므). Det ser ut til at viruset sjelden infiserer fosteret over placenta, selv om det i noen tilfeller er påvist i placenta og fostervann (7.). For enkelte maternelle infeksjoner er det observert økt risiko for helseplager, også psykiske lidelser, hos barnet på sikt. Spørsmålet er om dette også gjelder for covid-19 (모).

Men kanskje er det ikke covid-19 i seg selv som er pandemiens største trussel for gravide og kommende generasjoner. Stress tidlig i svangerskapet har vist seg å være assosiert med $ø \mathrm{kt}$ psykisk sykelighet hos barnet (5). Tidligere kriser har vist at mødres helse og eksponering for stress, miljøfaktorer, dårlig ernæring etc. før og i svangerskapet ikke bare har betydning for barnets helse, men også setter spor i neste generasjon gjennom epigenetiske mekanismer. Forsdahl-Barker-hypotesen og hypotesen om føtal opprinnelse er betegnelser som har vært brukt om betydningen av forhold tidlig i livet for senere utvikling og helse (9.).

I en nylig publisert studie (므) fant man ingen assosiasjon mellom maternell covid-19-status og barnets nevrologiske utvikling ved seks måneders alder, men man fant at barna som ble født under pandemien, uavhengig av maternell covid-19-status, skåret lavere på nevrokognitive tester enn en historisk barnekohort. Forfatterne av studien foreslår at covid-19-relatert stress i svangerskapet kan være en forklaring, hvilket betyr at vi kan stå foran en betydelig folkehelsekrise for generasjonen som blir født under pandemien. Funnene er neppe helt overførbare til norske forhold, men de er likevel tankevekkende og helt i tråd med funnene til Eberhard-Gran og medarbeidere (3).

Gravides bekymring for selve koronavirusinfeksjonen kan avhjelpes med vaksinasjon, som vi etter hvert vet er trygt og effektivt, også for gravide. I Norge var fortsatt bare $60 \%$ av dem som fødte i desember 2021, vaksinert (F. Macsali, Folkehelseinstituttet, personlig meddelelse). Økt motivering av gravide til å ta vaksine og flere tiltak overfor småbarnsforeldre for å forebygge psykologiske konsekvenser av pandemien er påkrevd. Vi trenger også studier om effektene av pandemi og infeksjonseksponering. Gravide, fødende og småbarnsmødre er en stor og sårbar del av befolkningen. Regjeringens ekspertgruppe har overlatt dem til seg selv (11). Konsekvensene kan sette spor over generasjoner.

\section{LITTERATUR}

1. Epelboin S, Labrosse J, De Mouzon J et al. Obstetrical outcomes and maternal morbidities associated with COVID-19 in pregnant women in France: A national retrospective cohort study. PLoS Med 2021; 18: e1003857. [PubMed][CrossRef]

2. Khalil A, Blakeway H, Samara A et al. COVID-19 and stillbirth: direct vs indirect effect of the pandemic. Ultrasound Obstet Gynecol 2021; 58: uog.24846. [PubMed][CrossRef]

3. Eberhard-Gran M, Engelsen LY, Al-Zirqi I et al. Depressive symptomer og fødselsopplevelse hos spedbarnsmødre under covid-19-pandemien Tidsskr Nor Legeforen 2022;142. doi: 10.4045/tidsskr.21.0450. [CrossRef]

4. Lebel C, MacKinnon A, Bagshawe $M$ et al. Elevated depression and anxiety symptoms among pregnant individuals during the COVID-19 pandemic. J Affect Disord 2020; 277: 5-13. [PubMed] [CrossRef]

5. Monk C, Lugo-Candelas C, Trumpff C. Prenatal developmental origins of future psychopathology: mechanisms and pathways. Annu Rev Clin Psychol 2019; 15: 317-44. [PubMed][CrossRef]

6. Garcia-Flores V, Romero R, Xu Y et al. Maternal-fetal immune responses in pregnant women infected with SARS-CoV-2. Nat Commun 2022; 13:320. [PubMed][CrossRef]

7. Mao Q, Chu S, Shapiro S et al. Placental SARS-CoV-2 distribution correlates with level of tissue oxygenation in COVID-19-associated necrotizing histiocytic intervillositis/perivillous fibrin deposition. Placenta 2022; 117: 187-93. [PubMed][CrossRef]

8. Zimmer A, Youngblood A, Adnane A et al. Prenatal exposure to viral infection and neuropsychiatric disorders in offspring: A review of the literature and recommendations for the COVID-19 pandemic. Brain Behav Immun 2021; 91: 756-70. [PubMed][CrossRef] 
9. Vangen S, Nordhagen R, Lie KK. Gjensyn med Forsdahl-Barker-hypotesen. Tidsskr Nor Lægeforen 2005; 125: 451-3. [PubMed]

10. Shuffrey LC, Firestein MR, Kyle MH et al. Association of birth during the COVID-19 pandemic with neurodevelopmental status at 6 months in infants with and without in utero exposure to maternal SARS-CoV-2 infection. JAMA Pediatr 2022; 176: e215563. [PubMed][CrossRef]

11. Livskvalitet, psykisk helse og rusmiddelbruk under Covid-19-pandemien. Rapport fra regjeringsoppnevnt ekspertgruppe.

https://www.regjeringen.no/contentassets/f3f79foeoacf4aebaao5d17bfdb4fb28/rapport-fraekspertgruppe-livskvalitet-psykisk-helse-og-rusmiddelbruk.pdf Lest 23.1.2022.

Publisert: 4. februar 2022. Tidsskr Nor Legeforen. DOI: 10.4045/tidsskr.22.0053

(C) Tidsskrift for Den norske legeforening 2023. Lastet ned fra tidsskriftet.no 26. april 2023. 